\title{
Comparison between optical coherence tomography and intravascular ultrasound in detecting neointimal healing patterns after stent implantation
}

\author{
Janusz Kochman ${ }^{1}$, Arkadiusz Pietrasik ${ }^{1}$, Adam Rdzanak ${ }^{1}$, Jacek Jąkała ${ }^{2}$, Wojciech Zasada², Anna Ścibisz ${ }^{1}$, \\ Łukasz Kołtowski ${ }^{1}$, Klaudia Proniewska ${ }^{2}$, Elżbieta Pociask ${ }^{2}$, Jacek Legutko ${ }^{3}$ \\ ${ }^{1} 1^{\text {st }}$ Department of Cardiology, Medical University of Warsaw, Poland \\ ${ }^{2}$ Krakow Cardiovascular Research Institute, Krakow, Poland \\ ${ }^{3}$ Department of Interventional Cardiology, Jagiellonian University, Krakow, Poland
}

\begin{abstract}
A b stract
Background: The amount of data comparing intravascular ultrasound (IVUS) and optical coherence tomography (OCT) for the detection of stent coverage in clinical settings is limited.

Aim: To make a qualitative and quantitative assessment of the vascular healing patterns in patients after stent implantations visualised by both IVUS and OCT.

Methods: Images were obtained in patients with clinical symptoms of angina, who had had a bare metal stent implanted in the previous 12 months. Angiography, IVUS and OCT were performed in 14 coronary arteries. Measurements of stent, lumen and neo-intima areas and dimensions were performed in stented regions and in both $10 \mathrm{~mm}$ references. IVUS, OCT, and angiographic data were compared in matched regions. Off-line analyses were performed by an independent core lab.

Results: 14 stents were imaged without any procedural complications. The nominal stent length was $28 \pm 4.5 \mathrm{~mm}$. OCT was the most accurate technique for assessing stent length $(28.12 \pm 6.8 \mathrm{~mm})$, while QCA underestimated length due to foreshortening $(22.16 \pm 6.39 \mathrm{~mm})$ and IVUS was vulnerable to random error due to discontinuous pullbacks and vessel movements $(24.21 \pm 7.90 \mathrm{~mm})$. Minimum lumen area (MLA) and minimum lumen diameter (MLD) in reference sites were comparable in IVUS and OCT, whereas there were significant differences between these two modalities for MLA $\left(3.30 \pm 1.49\right.$ vs. $\left.2.19 \pm 1.30 \mathrm{~mm}^{2}, \mathrm{p}=0.0046\right)$ and for MLD $\left(2.42 \pm 0.51\right.$ vs. $\left.1.58 \pm 0.56 \mathrm{~mm}^{2}, \mathrm{p}=0.0023\right)$ in stented segments. There was a slight overestimation of lumen volume (130.18 $\left.\pm 70.61 \mathrm{vs} .117 .82 \pm 67.02 \mathrm{~mm}^{3}, \mathrm{p}=0.7256\right)$, a marked overestimation of stent volume (179.29 \pm 97.58 vs. $\left.226.46 \pm 108.76 \mathrm{~mm}^{3}, \mathrm{p}=0.0544\right)$ and a statistically significant difference in the neointima volume $\left(49.11 \pm 39.70\right.$ vs. $\left.108.64 \pm 43.77 \mathrm{~mm}^{3}, \mathrm{p}=0.0060\right)$ by IVUS compared to OCT. Mean neointima burden in IVUS was much smaller than in OCT $(20.79 \pm 14.27 \%$ vs. $58.16 \pm 18.25 \%$, $p=0.0033)$. Conclusions: OCT can precisely quantify struts coverage and is more accurate than IVUS in the assessment of vascular healing in patients after stent implantation.
\end{abstract}

Key words: angiography, IVUS, OCT, in-stent restenosis, neointima

Kardiol Pol 2014; 72, 6: 534-540

\section{INTRODUCTION}

Coronary angiography remains a gold standard in determining the mode of treatment in patients with coronary artery disease.
However, it has many limitations that hamper accurate and appropriate vessel assessment [1-3]. Therefore intravascular ultrasound (IVUS) - a more accurate method of intralumi-

\section{Address for correspondence:}

Janusz Kochman, MD, $1^{\text {st }}$ Department of Cardiology, Medical University of Warsaw, ul. Żwirki i Wigury 61, 02-091 Warszawa, Poland, e-mail: jkochman@wum.edu.pl Received: 17.07.2013 Accepted: 28.10.2013 Available as AoP: 07.11.2013

Copyright (C) Polskie Towarzystwo Kardiologiczne 
nal imaging - for many years has played an important role in understanding failure and optimising outcome of stent implantation. A key insight from IVUS includes the significance of complete expansion and apposition of the stent, its influence on late lumen loss and the occurrence of in-stent restenosis. However, due to the relatively low resolution $(150-200 \mu \mathrm{m})$ and high reflectivity of metallic stent struts, IVUS cannot provide detailed information that could improve understanding of the mechanisms of vascular healing [4, 5]. The newest intravascular invasive imaging modality - optical coherence tomography (OCT) - is a novel method that employs near-infrared light to improve resolution (10-15 $\mu \mathrm{m})$ of obtained images. Therefore OCT has emerged as a promising modality for the precise follow up quantification of tissue growth and strut coverage $[6,7]$. However the clinical data concerning a direct comparison of IVUS and OCT in patients after stent implantation is still lacking.

The aim of the present study was to evaluate the correlation between OCT and IVUS measurements in this group of patients.

\section{METHODS}

Study design and patient population

The study population comprised patients with symptoms of progressive angina after previous bare metal stent implantation. All patients had a bare metal stent implanted $8 \pm 3$ months before IVUS and OCT examination. This study was conducted in accordance with the Declaration of Helsinki and protocol approval was obtained from the Local Ethics Committee of the Medical University of Warsaw.

\section{Intravascular imaging}

Coronary angiography was performed in a standard manner with 6 French guiding catheters. An automated $(0.5 \mathrm{~mm} / \mathrm{s})$ IVUS pullback was performed from the distal segment of an artery to the proximal part - more than $10 \mathrm{~mm}$ from the proximal edge of a stent, after intracoronary administration of $200 \mu \mathrm{g}$ of nitroglycerine. IVUS was performed using solid state system with Eagle Eye Gold ${ }^{\circledR}$ phased array IVUS probes (Volcano Corp, Rancho Cordova, CA, USA). Following IVUS imaging, the OCT catheter was advanced over the guide wire and placed at the distal part of a vessel (minimum $10 \mathrm{~mm}$ from the distal edge of a stent). The OCT images were obtained with the C7 OCT imaging system with Dragonfly ${ }^{\circledR}$ image wires (LightLab Imaging Inc., Westford, MA, USA). To image the vessel, the blood in coronary arteries was replaced with a mixture of saline and angiographic contrast using a manual syringe. OCT imaging was performed at a pullback speed rate of $20 \mathrm{~mm} / \mathrm{s}$.

\section{Data analysis}

Off-line, qualitative and quantitative coronary angiography (QCA), grey-scale IVUS, and OCT analyses were performed by an independent core laboratory (Krakow Cardiovascular Research Institute [KCRI], Krakow, Poland). QCA analysis was performed using Sanders Data Systems QCA Plus software (Palo Alto, CA, USA) according to previously validated and published protocols. The core laboratory was blinded to the clinical and procedural information. Reference vessel diameter, minimal lumen diameter (MLD), per cent diameter stenosis and lesion length were collected for each vessel. The grey-scale IVUS analysis was performed using echoPlaque 4 software (Indec Medical Systems, Santa Clara, CA, USA). Contour detection of the lumen and media-adventitia interface was performed. The IVUS analysis was performed according to the guidelines of the American College of Cardiology [8]. The OCT measurements were performed with LightLab OCT imaging proprietary software by an analyst blinded to the IVUS and angiographic results. The system was calibrated to the reflection of the OCT imaging wire, which is the standard calibration technique for this system. Then areas were manually traced. The OCT analysis was performed according to previously described methods [9, 10]. The registered IVUS and OCT datasets were evaluated to identify in-stent: MLD [mm], minimum lumen area (MLA $\left.\left[\mathrm{mm}^{2}\right]\right)$, intima and lumen volumes $\left[\mathrm{mm}^{3}\right]$ and the presence of incomplete apposition of stent to vessel wall. Additionally, MLA and MLD at reference sites were measured.

\section{Statistical analysis}

Statistical analysis was performed using the JMP software, version 9.0.0 (SAS Institute, Cary, NC, USA). All values are expressed as means \pm standard deviations (continuous variables) or as count and percentage (categorical variables). Continuous variables were compared with a nonparametric Mann-Whitney test. Categorical variables were compared with $\chi^{2}$ test. Bland-Altman plots were performed to show agreement between IVUS and OCT measurements. Then the Bland-Altman plots were calculated using paired t-test and paired Wilcoxon test to assess the differences between both methods. A probability value $<0.05$ was considered significant. For the purposes of the Bland-Altman plots, all the IVUS and OCT frames were taken into account of this particular analysis. Due to the fact that in IVUS pullbacks there were different numbers of analysed frames per one unit of length than in OCT pullbacks, values from one OCT frame were compared with mean results from several corresponding IVUS frames. The number of corresponding frames depended on the proportion of numbers of frames in both methods (IVUS and OCT) and is different for each patient.

\section{RESULTS}

The study population comprised 14 prospectively enrolled patients (11 [78.6\%] men and three [21.4\%] women, mean age 69.1 [11.8] years, range 45-86 years]) with clinical symptoms of angina, who had had a bare metal stent implanted 
Table 1. Baseline characteristics of the patients

\begin{tabular}{|lc|}
\hline Age [years] & $69.1 \pm 11.8$ \\
Males & $11(78.6 \%)$ \\
Hypertension & $9(64.3 \%)$ \\
Dyslipidaemia & $11(78.6 \%)$ \\
Diabetes mellitus & $3(21.4 \%)$ \\
Smoking & $8(57.1 \%)$ \\
Previous stroke & $1(7.1 \%)$ \\
Chronic kidney disease & $1(7.1 \%)$ \\
Ejection fraction [\%] & $58 \pm 5.6$ \\
Stable angina & $14(100 \%)$ \\
\hline
\end{tabular}

Table 2. Quantitative coronary angiography $(n=14)$ measurements in analysed segments

\begin{tabular}{|lc|}
\hline Minimum reference diameter $[\mathrm{mm}]$ & $3.01 \pm 0.50$ \\
Minimum lumen diameter $[\mathrm{mm}]$ & $1.29 \pm 0.23$ \\
Diameter stenosis [\%] & $56.54 \pm 9.09$ \\
Stent length $[\mathrm{mm}]$ & $22.16 \pm 6.39$ \\
\hline
\end{tabular}

in the previous 12 months because of single coronary artery disease. In all 14 vessels, stents with references were imaged, including left anterior descending coronary artery $(n=3)$, circumflex coronary artery $(n=6)$, and right coronary artery $(n=5)$. IVUS and OCT examinations were successfully performed in all analysed segments. Clinical data and measurements by angiography in analysed segments are shown in Tables 1 and 2. The nominal stent length was $28 \pm 4.5 \mathrm{~mm}$. OCT was the most accurate technique to measure stent length $(28.12 \pm 6.83 \mathrm{~mm})$. The measurements obtained with other methods were less precise. QCA underestimated length due to foreshortening $(22.16 \pm 6.39 \mathrm{~mm})$ and IVUS due to discontinuous pullbacks $(24.21 \pm 7.90 \mathrm{~mm})$. Volumetric calculations by IVUS are therefore less reliable than those obtained with OCT (Table 3). Minimum lumen area and minimum lumen diameter in reference sites were comparable in IVUS and OCT analysis. There was a tendency to overestimate lumen volume $\left(130.18 \pm 70.61 \mathrm{~mm}^{3}, 117.82 \pm 67.02 \mathrm{~mm}^{3}\right.$, respectively, $\mathrm{p}=0.7256)$ and underestimate stent $\left(179.29 \pm 97.58 \mathrm{~mm}^{3}\right.$, $226.46 \pm 108.76 \mathrm{~mm}^{3}$, respectively, $\mathrm{p}=0.0544$ ) and there was a statistically significant difference in intima volume measurements $\left(49.11 \pm 39.70 \mathrm{~mm}^{3}, 108.64 \pm 43.77 \mathrm{~mm}^{3}\right.$, respectively, $p=0.0060$ ) by IVUS compared to OCT (Tables 3,4). Similar results were seen in stented segments assessed by IVUS and OCT for MLA $\left(3.30 \pm 1.49 \mathrm{~mm}^{2}\right.$, $2.19 \pm 1.30 \mathrm{~mm}^{2}$, respectively, $\mathrm{p}=0.0046$ ) and for MLD $\left(2.42 \pm 0.51 \mathrm{~mm}^{2}, 1.58 \pm 0.56 \mathrm{~mm}^{2}\right.$, respectively, $\mathrm{p}=0.0023$ ). Bland-Altman plots (Fig. 1) revealed the difference between the measurements in OCT and IVUS - mainly in dimension and area measurements. There is a systematic disagreement between these two modalities, as IVUS overestimates lumen area/volume and underestimates stent and intima area/volume compared to OCT (Figs. 1, 2). Malappositions were not observed in any patient. In IVUS, none of the patients had a neointima burden of more than $40 \%$ and in OCT five of them had a neointima burden of more than $50 \%$. Mean neointima burden in IVUS was much smaller than in OCT $(20.79 \pm 14.27 \%, 58.16 \pm 18.25 \%$, respectively, $p=0.0033$ ) (Table 4). Representative matched images of OCT and IVUS are shown in Figure 3.

\section{DISCUSSION IVUS and OCT results}

OCT, a novel method of intraluminal imaging, has been found to be useful in the assessment of the healing process post stent implantation. The aim of the present study was

Table 3. Intravascular ultrasound (IVUS) and optical coherence tomography (OCT) parameters in all stents and reference segments

\begin{tabular}{|c|c|c|c|}
\hline & IVUS $(n=14)$ & OCT $(n=14)$ & $\mathbf{P}$ \\
\hline \multicolumn{4}{|l|}{ Reference segments } \\
\hline Distal Ref MLD [mm] & $1.81 \pm 0.38$ & $1.70 \pm 0.66$ & 0.2665 \\
\hline Distal Ref MLA [mm²] & $3.70 \pm 1.67$ & $3.69 \pm 2.68$ & 0.4263 \\
\hline Proximal Ref MLD [mm] & $2.45 \pm 0.64$ & $1.92 \pm 0.23$ & 0.0244 \\
\hline Proximal Ref MLA [mm²] & $5.87 \pm 3.26$ & $4.36 \pm 1.53$ & 0.0902 \\
\hline \multicolumn{4}{|l|}{ Stented segment } \\
\hline Stent length $[\mathrm{mm}]$ & $24.21 \pm 7.90$ & $28.12 \pm 6.83$ & 0.0321 \\
\hline Stent MLD [mm] & $2.42 \pm 0.51$ & $1.58 \pm 0.56$ & 0.0023 \\
\hline Stent MLA [mm²] & $3.30 \pm 1.49$ & $2.19 \pm 1.30$ & 0.0046 \\
\hline Lumen volume $\left[\mathrm{mm}^{3}\right]$ & $130.18 \pm 70.61$ & $117.82 \pm 67.02$ & 0.7256 \\
\hline Stent volume $\left[\mathrm{mm}^{3}\right]$ & $179.29 \pm 97.58$ & $226.46 \pm 108.76$ & 0.0544 \\
\hline
\end{tabular}

MLA — minimum lumen area; MLD — minimum lumen diameter; Ref — reference 
Table 4. Intravascular ultrasound (IVUS) and optical coherence tomography (OCT) parameters in all stents. Analysis of IVUS pullback was performed with the step $0.5 \mathrm{~mm}$ and OCT with the step $0.2 \mathrm{~mm}$

\begin{tabular}{lccc} 
& IVUS $(\mathbf{n}=\mathbf{1 4})$ & OCT $(\mathbf{n}=\mathbf{1 4})$ & P \\
\hline Mean number of cross sections included & $58.0 \pm 7.0$ & $150.2 \pm 25.2$ & 0.0313 \\
to the analysis per patient & & & 0.0313 \\
Mean number of analysed struts per patient & $492.5 \pm 111.0$ & $1,489.7 \pm 452.5$ & 0.0313 \\
Mean number of apposed struts per patient & $492.5 \pm 111.0$ & $1,489.7 \pm 452.5$ & NA \\
Mean number of malapposed struts per patient & 0 & 0 & 0.0313 \\
Maximal neointimal thickness [mm] & $0.71 \pm 0.36$ & $1.03 \pm 0.41$ & 0.0060 \\
Intima volume [mm ${ }^{3}$ [m & $49.11 \pm 39.70$ & $58.16 \pm 18.25$ & 0.0033 \\
Intima burden [\%] & $20.79 \pm 14.27$ & & \\
\hline
\end{tabular}



Figure 1. Comparison of the lumen area evaluated by optical coherence tomography (OCT) and intravascular ultrasound (IVUS) (A) and Bland-Altman plot for OCT vs. IVUS in the measurement of lumen area (B)
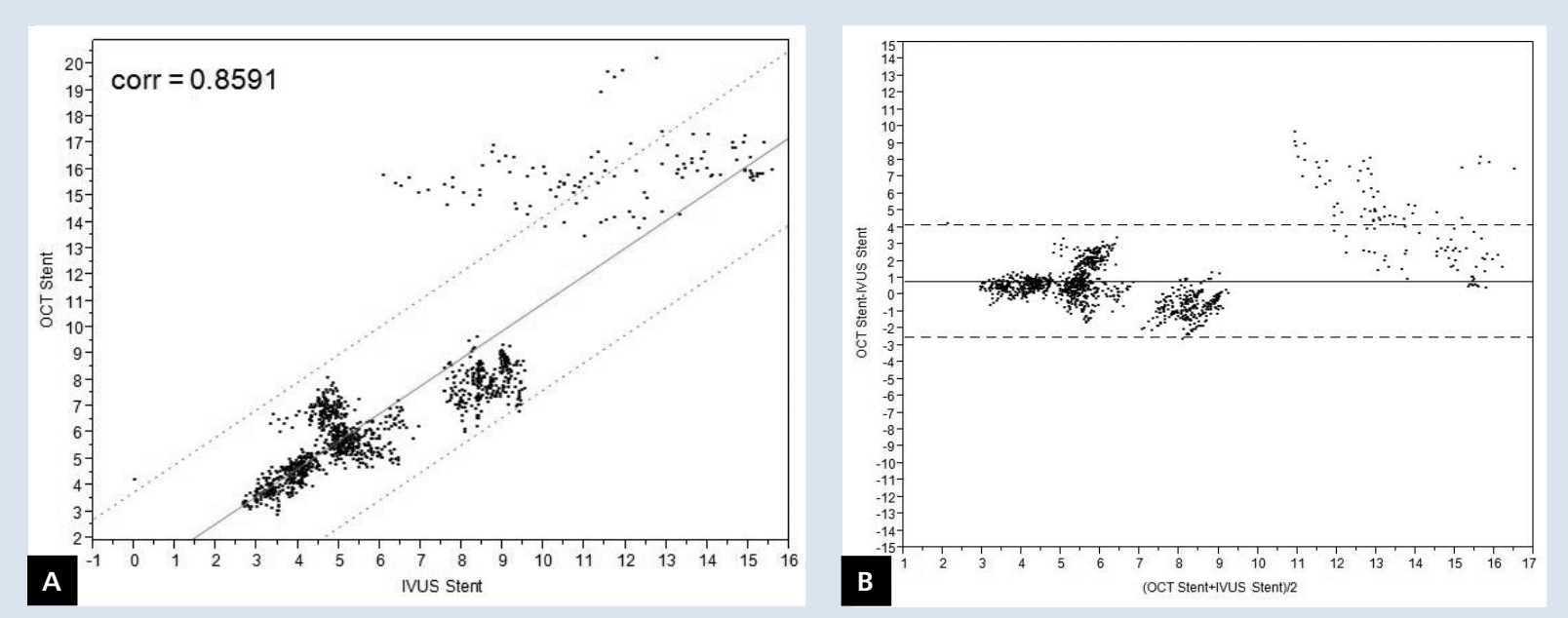

Figure 2. Comparison of the lumen area evaluated by optical coherence tomography (OCT) and intravascular ultrasound (IVUS) (A) and Bland-Altman plot for OCT vs. IVUS in the measurement of stent area (B) 

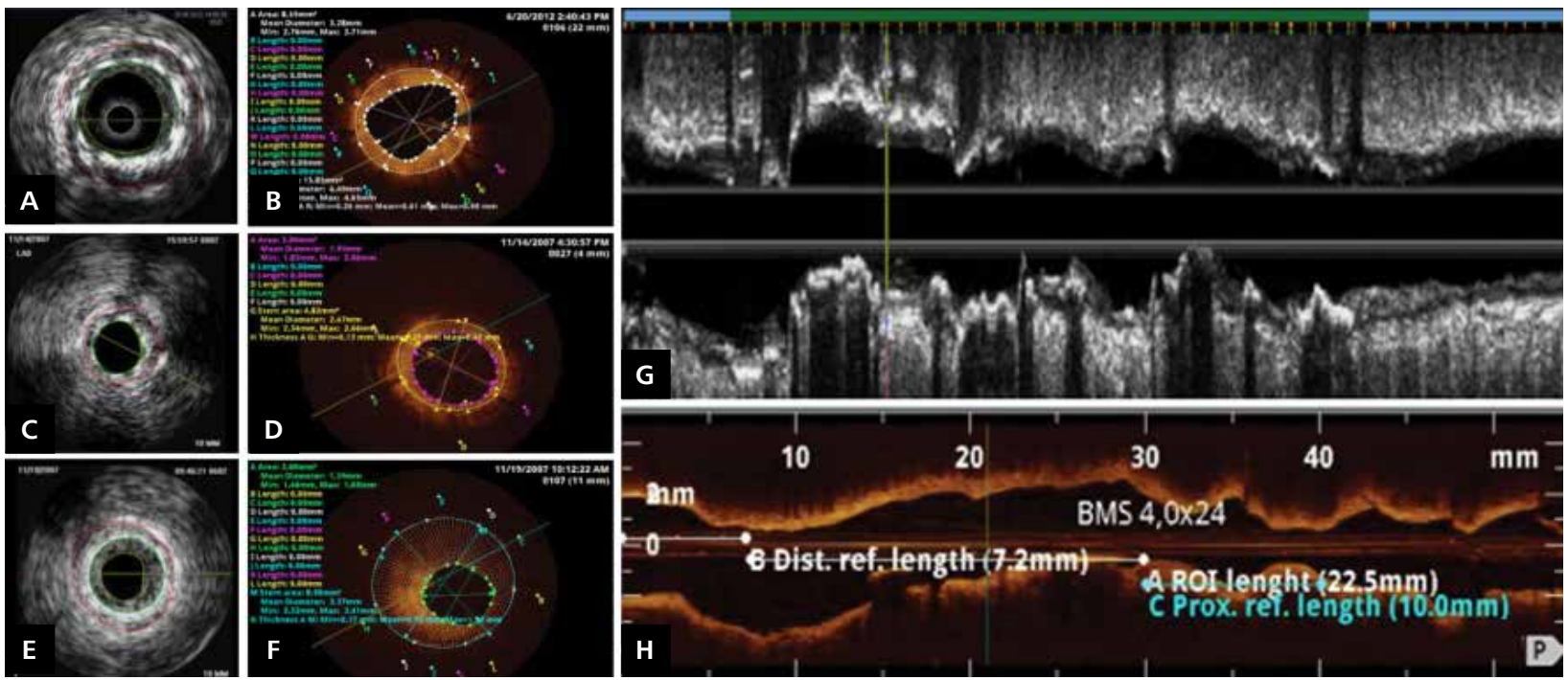

Figure 3. Matched images of optical coherence tomography (OCT) and intravascular ultrasound (IVUS); A, B. Small intimal hyperplasia seen in IVUS and OCT; C, D. Region with normal stent apposition; intimal coverage in intravascular pullback is not seen due to lower resolution of this method; E, F. In OCT intimal burden is more pronounced than in IVUS; G, H. Longitudinal view of IVUS and OCT pullbacks

to compare OCT findings with IVUS examination, which is still considered to be the gold standard of post percutaneous coronary intervention evaluation.

The major findings of this study are: 1) IVUS overestimated lumen area/volume and underestimated stent and intima area/volume compared to OCT; 2) IVUS and OCT modalities proved to be complementary rather than competitive in the assessment of vessel healing after stent implantation.

Higher resolution of images obtained with OCT allows precise differentiation between elements of the lumen-stent/vessel border, and therefore the measurements are more accurate compared to IVUS. A growing body of evidence suggests that IVUS tends to overestimate the lumen area compared to OCT. Our results confirmed that IVUS overestimates lumen area and underestimates neointima volume and neointima burden. Although IVUS is thought to be a reliable modality for the assessment of the mechanism of in stent restenosis, due to relatively low resolution it is not able to detect small amounts of tissue covering stent strut and is not capable of exact visualisation of the border between soft structures and blood. OCT, due to its more precise assessment of the neointima-stent borders, provides more accurate images. Although IVUS showed higher values of lumen area and lower values of stent area, a correlation between OCT and IVUS measurements could be observed

The major limitations of OCT examination include limited penetration and the need to replace blood in the examined vessel with optically translucent fluid. This can be performed using both occlusive $[5,11]$ and non-occlusive techniques $[6,7,12]$. Our study utilised a non-occlusive OCT catheter system, which has a smaller profile and moves inside a sheath, allowing more homogenous pullback than the one acquired with an IVUS probe. Therefore the length measurements obtained with OCT are more reliable. Our findings are consistent with previous findings reported by Gonzalo et al. [12] and Capodanno et al. [7], who also observed overestimation of lumen measurements in IVUS compared to OCT and found a correlation between the two studied methods.

Due to the excellent resolution of obtained images, OCT allows also more accurate evaluation of neointimal thickness and distribution. Moreover, tissue coverage and apposition of each stent strut might be detected and precisely quantified. Contradicting previously published data, in our study no late stent malapposition was detected. This finding can be partially explained due to the small sample size. Furthermore, all examined patients had had a bare metal stent implanted $8 \pm 3$ months before OCT examination, which might have been sufficient time for the healing of any possible malapposition to occur.

In current clinical practice, IVUS examination remains the gold standard in periprocedural vessel assessment and guiding of percutaneous procedures. IVUS has also been considered to be the method of choice in the evaluation of long term outcomes after stent implantation and contributed to the understanding of in-stent restenosis pathology. Since OCT provides additional information on plaque composition stent appearance and strut coverage, in the future it might replace IVUS in the assessment of implanted stent. However, low penetration of currently available systems, which remains the major drawback of this novel technique, limits its utility in the comprehensive assessment of entire coronary vessels $[13,14]$. 


\section{Limitations of the study}

Technical limitations included the difficulty in exactly matching regions from angiography, OCT, and IVUS. The study was also limited by the small sample size. In OCT modality, delivery of the mixture of saline and contrast through the guide catheter in order to displace blood was sometimes inefficient, especially in the case of distal vessel segments with occlusive lesions and prominent side branches. Movement during the heart cycle or non-continuous pullbacks tend to produce non-corresponding IVUS and OCT cross-sectional measurements.

\section{CONCLUSIONS}

OCT examination provides more detailed structural information than IVUS. Also, the better resolution of OCT enables more accurate outline of the stent struts. IVUS, the current gold standard method of post percutaneous coronary intervention evaluation, has insufficient resolution to detect the exact lumen-neointima border, which seems to be the main reason for the discrepancies in area measurements between studied modalities.

This research was supported with a scientific grant from the Polish Ministry of Science, grant number: N N403 293236.

\section{Conflict of interest: none declared}

\section{References}

1. Spears JR, Sandor T, Als AV et al. Computerized image analysis for quantitative measurement of vessel diameter from cineangiograms. Circulation, 1983; 68: 453-461.

2. Regar E, Werner F, Siebert U et al. Reproducibility of neointima quantification with motorized intravascular ultrasound pullback in stented coronary arteries. Am Heart J, 2000; 139: 632-637.

3. Lermusiaux P, Martinez R, Donadey A et al. Intravascular ultrasound: limitation and prospects. J Mal Vasc, 2000; 25: 229-236.

4. Takano M, Inami S, Jang IK et al. Evaluation by optical coherence tomography of neointimal coverage of sirolimus-eluting stent three months after implantation. Am J Cardiol, 2007; 99: 1033-1038.
5. Kawamori H, Shite J, Shinke T et al. The ability of optical coherence tomography to monitor percutaneous coronary intervention: detailed comparison with intravascular ultrasound. J Invasive Cardiol, 2010; 22: 541-545.

6. Ramesh S, Papayannis A, Abdel-karim A et al. In vivo comparison of Fourier-domain optical coherence tomography and intravascular ultrasonography. J Invasive Cardiol, 2012; 24: 111-115.

7. Capodanno D, Prati F, Pawłowski T et al. Comparison of optical coherence tomography and intravascular ultrasound for the assessment of in-stent tissue coverage after stent implantation. EuroIntervention, 2009; 5: 538-543.

8. Mintz GS, Nissen SE, Anderson WD et al. American College of Cardiology clinical expert consensus document on standards for acquisition, measurement, and reporting of intravascular ultrasound studies (IVUS). A report of the American College of Cardiology Task Force on Clinical Expert Consensus Documents. J Am Coll Cardiol, 2001; 37: 1478-1492.

9. Prati F, Regar E, Mintz GS et al. Expert review document on methodology, terminology, and clinical applications of optical coherence tomography: physical principles, methodology of image acquisition, and clinical application for assessment of coronary arteries and atherosclerosis. Eur Heart J, 2010; 31: 401-415.

10. Prati F, Guagliumi G, Mintz GS et al. Expert review document part 2: methodology, terminology and clinical applications of optical coherence tomography for the assessment of interventional procedures. Eur Heart J, 2012; 33: 2513-2520.

11. Yamaguchi T, Terashima M, Akasaka T et al. Safety and feasibility of an intravascular optical coherence tomography image wire system in the clinical setting. Am J Cardiol, 2008; 101: 562-567.

12. Gonzalo N, Serruys PW, García-García HM et al. Quantitative ex vivo and in vivo comparison of lumen dimensions measured by optical coherence tomography and intravascular ultrasound in human coronary arteries. Rev Esp Cardiol, 2009; 62: 615-624.

13. Guagliumi G, Sirbu V, Bezerra H et al. Strut coverage and vessel wall response to zotarolimus-eluting and bare-metal stents implanted in patients with ST-segment elevation myocardial infarction: the OCTAMI (Optical Coherence Tomography in Acute Myocardial Infarction) Study. J Am Coll Cardiol Cardiovasc Interv, 2010; 3: 680-687.

14. Guagliumi G, Musumeci G, Sirbu V et al. A prospective randomized controlled study using optical coherence tomography to evaluate the strut coverage of sirolimus-, paclitaxel-, zotalorimus-eluting coronary stents for long lesions requiring overlapping. ODESSA-OCT for DES Safety. J Am Coll Cardiol Intv, 2010; 3: 531-539. 


\title{
Porównanie optycznej koherentnej tomografii i wewnątrznaczyniowej ultrasonografii w ocenie procesu endotelizacji po zabiegach implantacji stentu
}

\author{
Janusz Kochman ${ }^{1}$, Arkadiusz Pietrasik ${ }^{1}$, Adam Rdzanak ${ }^{1}$, Jacek Jąkała ${ }^{2}$, Wojciech Zasada ${ }^{2}$, Anna Ścibisz ${ }^{1}$, \\ Łukasz Kołtowski ${ }^{1}$, Klaudia Proniewska², Elżbieta Pociask ${ }^{2}$, Jacek Legutko ${ }^{3}$ \\ II Katedra i Klinika Kardiologii, Warszawski Uniwersytet Medyczny, Warszawa \\ ${ }^{2}$ Krakow Cardiovascular Research Institute, Kraków \\ ${ }^{3}$ Klinika Kardiologii Interwencyjnej, Uniwersytet Jagielloński, Kraków
}

\section{Streszczen i e}

Wstęp: Niewiele jest doniesień na temat porównania optycznej koherentnej tomografii (OCT) i wewnątrznaczyniowej ultrasonografii (IVUS) w ocenie stopnia endotelizacji po zabiegach implantacji stentu.

Cel: Celem badania była ilościowa i jakościowa ocena procesu endotelizacji z wykorzystaniem OCT i IVUS u chorych poddawanych angioplastyce wieńcowej z implantacją stentu.

Metody: Ocenie obrazowej poddano chorych z wszczepionym w ciągu ostatnich 12 miesięcy stentem konwencjonalnym. Koronarografię, OCT i IVUS wykonano łącznie w 14 tętnicach wieńcowych. Pomiary pola stentu, światła naczynia, grubości i objętości neointimy przeprowadzono w obrębie implantowanych stentów i w przylegających 10-mm odcinkach referencyjnych. Porównywano dane uzyskane z badania angiograficznego, OCT i IVUS, obejmujących te same segmenty naczynia. Wszystkie analizy zostały wykonane w niezależnym ośrodku badawczym.

Wyniki: Wizualizację 14 stentowanych segmentów przeprowadzono bez powikłań. Nominalna, średnia długość stentu wyniosła $28 \pm 4,5 \mathrm{~mm}$. OCT była najdokładniejszą metodą w ocenie długości stentu (28,12 \pm 6,8 mm), podczas gdy pomiary z wykorzystaniem ilościowej analizy angiograficznej (QCA) charakteryzowały się niedoszacowaniem długości stentu $(22,16 \pm 6,39 \mathrm{~mm})$. Pomiary IVUS zawierały z kolei błędy losowe związane z niejednostajnym przesuwaniem sondy i ruchami naczynia $(24,21 \pm 7,90 \mathrm{~mm})$. Minimalne pole powierzchni (MLA) i minimalna średnica światła naczynia (MLD) w odcinkach referencyjnych były porównywalne w IVUS i OCT, podczas gdy w obrębie implantowanych stentów odnotowano istotne różnice w pomiarach MLA (3,30 $\pm 1,49$ vs. 2,19 $\left.\pm 1,30 \mathrm{~mm}^{2}, p=0,0046\right)$ i MLD $\left(2,42 \pm 0,51\right.$ vs. $\left.1,58 \pm 0,56 \mathrm{~mm}^{2} ; p=0,0023\right)$. Obydwie wewnątrznaczyniowe techniki obrazowania wykazywały niewielką różnicę w ocenie objętości światła naczynia (130,18 \pm 70,61 vs. 117,82 $\pm 67,02$ mm33; $p=0,7256)$, nieco większą w objętości stentu $\left(179,29 \pm 97,58\right.$ vs. 226,46 $\left.\pm 108,76 \mathrm{~mm}^{3} ; p=0,0544\right)$ i statystycznie istotną w przypadku objętości neointimy $\left(49,11 \pm 39,70\right.$ vs. $\left.108,64 \pm 43,77 \mathrm{~mm}^{3} ; \mathrm{p}=0,0060\right)$, odpowiednio dla IVUS i OCT. Średni 'neointima burden' w ocenie za pomocą IVUS był znacząco mniejszy niż wyliczony na podstawie pomiarów OCT ( $20,79 \pm 14,27 \%$ vs. 58,16 $\pm 18,25 \%$; $\mathrm{p}=0.0033)$.

Wnioski: OCT pozwala precyzyjnie określić pokrycie elementów konstrukcyjnych stentu i jest metodą dokładniejszą w porównaniu z IVUS w ocenie procesu endotelizacji u chorych poddawanych implantacji stentu.

Słowa kluczowe: optyczna koherentna tomografia, wewnątrznaczyniowa ultrasonografia, angiografia, restenoza

Kardiol Pol 2014; 72, 6: 534-540 